\title{
STRENGTHENING BUSINESS CONTRACTS AND FOOD LABELING REGULATIONS IN SMALL AND MICRO BUSINESS IN SOUTH JAKARTA
}

\author{
Dessy SUNARSI ${ }^{1}$ and Rahmawati RAHMAWATI ${ }^{2 *}$ \\ ${ }^{1}$ Faculty of Law, Sahid University, Jakarta \\ ${ }^{2}$ Faculty of Food Technology and Health, Sahid University, Jakarta \\ *rahmafarasara@usahid.ac.id
}

\begin{abstract}
ABSTRACT. Business success is determined by one of them is legal protection for business. One form of legal protection is the creation of work contracts for all Cooperation with partners. The right employment contract will keep both parties mutually beneficial so that they can develop their business. In addition, businesses cannot develop if producers, especially food producers, do not have communicative labels, labels that can explain the condition of the products. For this reason, this training was held to strengthen MSMEs in making business contracts and making food labels that meet regulations and attract consumers. The training is carried out online with the media zoom meeting. The training was conducted using lecture, discussion, and video screening methods. The activity partners are MSMEs under the guidance of the Industry, Trade, Cooperatives, Small and Medium Enterprises, South Jakarta Administration. This training was attended by 174 small and micro entrepreneurs enthusiastically. The results of the evaluation showed that there was an increasing in knowledge in the both of trainings, in which the average score of business contract strengthening training was from 65,28 to 70,83 and for food labeling training from 62.73 to 75.31 .
\end{abstract}

Keywords: business contract, food, label, packaging, small business.

\section{BACKGROUND}

There are many things that determine success in business including business planning, market research, targeting, marketing, sales, cash flow management, human resource management and so on. However, that alone is not enough, there are other aspects that are no less important to pay attention to and fulfill if you want your business to be successful and last a long time.

This important aspect is legal protection for businesses. Business and law are two parts that cannot be separated, like a coin that has two sides. Ironically, this assumption that makes many entrepreneurs suffer losses, not even a few have collapsed. In the midst of increasingly sharp competition today, in addition to uncertainty over the life cycle of business development, especially in the midst of a pandemic condition that does not know when it will end, it is very important for every entrepreneur to make black and white, aka contracts, in establishing business relationships with partners. It's not just a capital of trust because the partners still have relatives or friends.

When running a business, business actors will always be involved in a transaction, both transactions with vendors and clients. Without realizing it, every day business actors make agreements with these parties, even though they are not directly stated in written form. Even though it is not in written form, it means that an agreement has been made based on the agreement. For example, when conducting business cooperation with colleagues or investors, both parties have made an agreement with the investor that will be included in the shareholder agreement, or when using the services provided by a vendor, usually the vendor will enter into a service provision agreement.

Basically, the contracts used for business transactions are known as business contracts. If a business contract has been made, then the contract will act as "law" for the parties involved, where the contract contains matters that regulate the rights and obligations of the parties, and can be used as legal evidence when a dispute occurs later.

A company, especially a company engaged in the food industry, would be nice if it had a clear and mutually beneficial business contract. However, the contract is meaningless if the product is not able to attract consumers to buy. One important factor in attracting consumers to buy is the label. This is because the label acts as a means of communication between producers and consumers. In making labels, producers must pay attention to the rules that have been made by the government, namely Government Regulation no. 69 of 1999 concerning Food Labels and Advertising (PP 69/1999). According to the regulation, food labels are "any information regarding food in the form of pictures, writings, a combination of both or other forms that are attached to food, inserted into, affixed to or part of food packaging". Food labels are required for every business actor who produces food domestically, as well as business actor who imports food for trade. The obligation to include labels on food is food that has gone through the final packaging process and is ready to be traded and does not apply to food that is packaged in front of the buyer. In PP 69/1999, exceptions are given for: a. food whose packaging is too small so that it is impossible to include all the information in question; b. food sold and packaged directly in front of the buyer in small quantities; c. food sold in large number or bulk.

To make it easier for producers to compile correct labels and assist consumers in understanding labelrelated matters, the government issued Law No.18 of 2012 concerning Food, in which the regulations and technical implementation were issued by the Food and Drug Supervisory Agency (BPOM). BPOM has issued regulations related to labeling through the head of BPOM regulation number 31 of 2018 concerning Processed Food Labels, number 13 of 2016 concerning Supervision of 
Claims on Processed Food Labels and Advertisements, no. 23 of 2016 concerning the inclusion of information without BTP on Food Labels and Advertisements, number 11 of 2019 concerning Food Additives, number 22 of 2019 concerning Information on Nutritional Values on Processed Food Labels, and lastly number 16 of 2020 concerning Inclusion of Nutritional Value Information on Processed Foods produced by MSEs. Another thing that becomes a point of attention in the regulation is that the information contained in the label is guaranteed to be correct and not misleading. Several provisions in the regulations related to this matter include:

1. Inclusion of halal label. In the event that a food product bears the label "halal", then the business actor is responsible for the truth. The truth of a "halal" label statement is not only proven in terms of raw materials, food additives, or auxiliary materials used, but must also be proven in the production process.

2. Loading certain claims. In the event that a food product includes a label containing a certain claim, then the business actor is responsible for the truth of the claim.

3. Health benefits. The inclusion of a statement about the benefits of food for health can only be done if it is supported by scientific facts that can be accounted for.

4. Function as medicine. The inclusion of the food concerned which can function as medicine is prohibited from being included in any form.

The problem is, there are still many manufacturers who do not understand the importance of the 2 things above. In order to improve understanding and strengthen the legal aspects of the matters mentioned above, an integrated entrepreneurship development training activity was carried out in the Industry, Trade, Cooperatives, Small and Medium Enterprises Office of South Jakarta administration for small and micro business entrepreneurs in the South Jakarta area. especially regarding strengthening business contracts and food labeling regulations for small and micro businesses in South Jakarta.

\section{METHODS}

The training activities are carried out online with the media zoom meeting. The method used is lecture, discussion, and film visualization. The lecture brainstorming method is used to provide a basic understanding of the importance of awareness of making business contracts in every business transaction carried out by training participants and how to regulate food packaging labels in accordance with applicable laws and regulations. Furthermore, the discussion method was carried out to improve their understanding through question and answer. While the film visualization method is given to strengthen people's understanding of what they already understand through lectures and discussions. In this case, film visualization is programmed to be given in the form of motivational shows to move the public to want to carry out this program, for example in showing how creative examples of packaging labels with attractive appearances and colorful graphic designs are made for domestic, local and brand label products. famous as material during webinars

The training materials provided are: (1) business contracts to support businesses; (2) Food labeling regulations. The business contracts to support businesses materials included the definition of the contract, terms of the validity of the agreement, the principles of contract law, the function of the contract, the things that must be considered in making the contract, default, some of the main factors that must be included in the contract, the steps for designing the contract, the contract structure, and making the contract. The food labeling regulations materials included the importance of food labels, the legal basis for food labeling, how to place labels on packaging, which can be affixed, inserted or printed on packaging, provisions for labeling, information that must be on the label and others.

Evaluation is done by online pretest and posttest. The questions were made with a multiple choice model. Respondents did on 7 questions for each material. So there were 14 questions.

\section{RESULTS AND DISCUSSIONS}

This webinar training was attended by 174 people, consisting of 134 women and 40 men. Participants are MSMEs who are under the guidance of the SubDepartment of Industry, Trade, Cooperatives, Small and Medium Enterprises of South Jakarta Administration (Perindustran, Perdagangan, Koperasi, Usaha Kecil dan Menengah/ PPKUKM South Jakarta), with data as below:

The webinar training was attended by 174 people. where 134 are women and 40 are men. The participants are MSMEs who are under the guidance of the SubDepartment of Industry, Trade, Cooperatives, Small and Medium Enterprises, South Jakarta Administrative City. The characteristics of the participants are presented below.

Table 1. The participant characteristics based on education level

\begin{tabular}{clc}
\hline No & \multicolumn{1}{c}{ Education level } & Amount \\
\hline 1 & Primary school & 13 \\
2 & Junior high school & 17 \\
3 & Senior High School & 90 \\
4 & DIPLOMA 1,2,3 & 20 \\
5 & Bachelor Degree & 32 \\
6 & Master Degree & 2 \\
\hline & Total & 174 \\
\hline
\end{tabular}

Source: South Jakarta PPKUKM

From the participant data, information was obtained that the participants were aged between 21 to 63 years old, who dominated by the productive age between 31 to 50 
years old as many as 108 people. This condition shows that there are many people who have the potential to be successful in entrepreneurship, so the government's role in fostering is very much needed.

Table 2. The participant characteristics based on types of business

\begin{tabular}{|c|c|c|}
\hline No & Business kinds & Amount \\
\hline 1 & Culinary & 121 \\
\hline 2 & Salon & 2 \\
\hline 3 & Service & 6 \\
\hline 4 & Commerce & 18 \\
\hline 5 & Convection & 1 \\
\hline 6 & Fashion & 13 \\
\hline 7 & Agribusiness and livestock & 13 \\
\hline
\end{tabular}

Source: South Jakarta PPKUKM

The webinar was opened with the delivery of a video from the governor of DKI, Mr. Anis Baswedan, and continued by Mr. Andriyanto P. as Head of MSMEs for the Industry, Trade, Cooperatives, Small and Medium Enterprises (Perindustran, Perdagangan, Koperasi, Usaha Kecil dan Menengah / PPKUKM) Sub-Department of South Jakarta Administration. The opening photo is shown in Figure 1. After the opening ceremony and welcome, the webinar participants were asked to take a pretest first. There are 174 webinar participants who take part in the pretest.

\subsection{Strengthening business contracts to support business}

The business contract material presented is related to the definition of the contract, terms of the validity of the agreement, the principles of contract law, the function of the contract, the things that must be considered in making the contract, default, some of the main factors that must be included in the contract, the steps for designing the contract, the contract structure, and making the contract. Memorandum of Understanding (MoU). Basically, there is no standard format for making contracts, so participants are invited to realize that it is important to make contracts in every business transaction carried out. The material is based on the Civil Code Book III concerning Engagement and Law no. 8 of 1999 concerning Consumer Protection. The material was delivered with lectures followed by video screenings and questions and answers. The photo of the presentation of the material is presented in Figure 2.

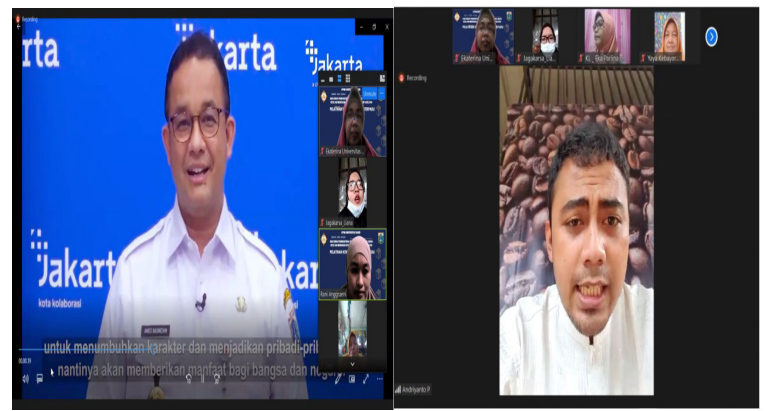

Figure 1. Opening by the Governor of DKI Jakarta Mr. Anis Baswedan and Mr. Andriyanto P. Head of the MSME Section of the Industry, Trade, Cooperatives, Small and Medium Enterprises Office, South Jakarta Administration
The provision of this material is expected to help MSMEs in making simple standard contracts and MoUs with their partners. Thus, it is hoped that MSME businesses can develop and be mutually beneficial between MSMEs and their partners wich legal certainty. This contract will protect the interests of the parties and will serve as evidence in the event of a dispute in the implementation of the business relationship.
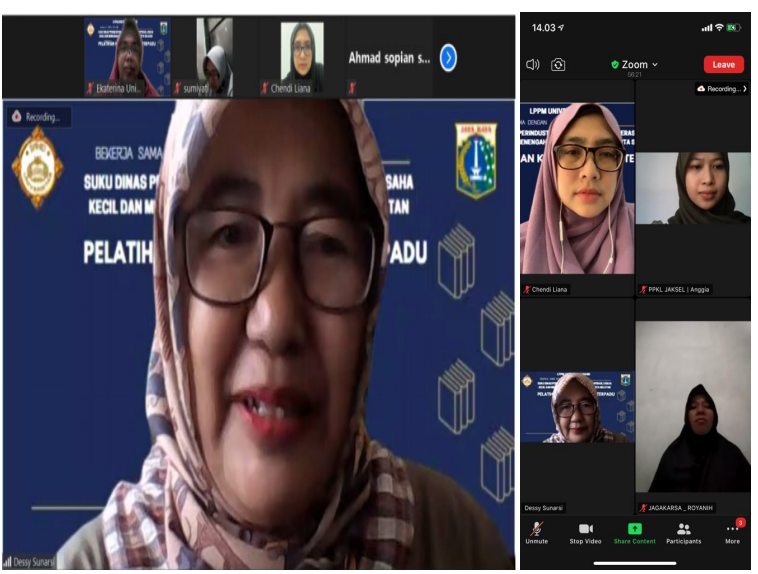

Figure 2. Presentation of material 1 regarding strengthening business contracts in supporting businesses

\subsection{Food Labeling Regulations}

Food labels are a means of communication between producers and consumers. Thus, the label becomes one of the factors that determine the selection of products to buy. Labels are very important for all food products on the market. To facilitate producers in making labels, the government has issued Law no. 18 of 2012 concerning Food, where one of the articles contains mandatory information that must be on the label. In addition, the government also issued regulations related to food labels, namely the regulation of the head of BPOM number 31 of 2018 concerning Processed Food Labels, number 13 of 2016 concerning Supervision of Claims on Processed Food Labels and Advertisements, no. 23 of 2016 concerning the inclusion of information without BTP on Food Labels and Advertisements, number 11 of 2019 concerning Food Additives, number 22 of 2019 concerning Information on Nutritional Values on Processed Food Labels, and lastly number 16 of 2020 concerning Inclusion of Nutritional Value Information on Processed Foods produced by MSEs.

Based on this, the material provided in this webinar includes: the importance of food labels, the legal basis for food labeling, how to place labels on packaging, which can be affixed, inserted or printed on packaging, provisions for labeling, information that must exist, namely: (1 ) Product Name : Type Name, Trade Name; (2) List of ingredients used/composition; (3) Net weight or net contents; (4) Name and address of the party producing or importing; (4) Halal for those who are required; (5) Production date and code; (6) Expiration date, month and year; (7) Distribution permit number; (8) Origin of certain foodstuffs; (9) The origin of certain foodstuffs. In addition, it is also studied regarding the use of writing, images, things that are not 
allowed, warning writings related to products containing pork, alcohol or the use of food additives (BTP) such as sweeteners, dyes, preservatives, and crunches. In 2020, a new BPOM regulation was issued regarding the obligation to include information on the nutritional value of food on processed food labels. Photos of webinar activities can be seen in Figure 3.

By participating in this webinar, it is hoped that MSME actors under the guidance of the South Jakarta PPKUKM service can increase their knowledge. Thus, business actors can make labels that are correct according to the rules, can reflect the condition of their products, and are made as attractive as possible so that their products can attract consumers to buy. Of course, it is hoped that this can improve marketing and develop business actors.

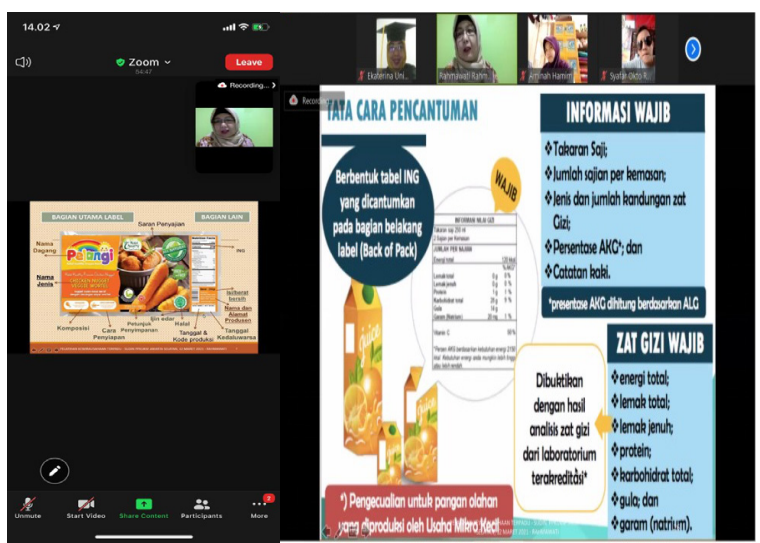

Figure 3. Presentation of material 2 regarding labeling of food products

\subsection{Activity Evaluation}

To see the success of the training, after finishing the webinar, participants are required to take a post test. Furthermore, the post-test and pre-test scores were compared. In general, the knowledge of business actors after participating in the two trainings increased. In business contract strengthening training, the average pretest score of participants is 65,28 , where the posttest score is 70,83 . Since the beginning, the participants have understood that the contract is very necessary, but at the implementation level, the technical aspects of contract drafting and very little understanding of the criteria for default. Likewise for food labeling training, the average pretest score is 62.73 , increasing to 75.31 at the post test. This means that participants take the training seriously so that this training increases the knowledge of business actors. The average value of the pretest and posttest are presented in Figure 4.
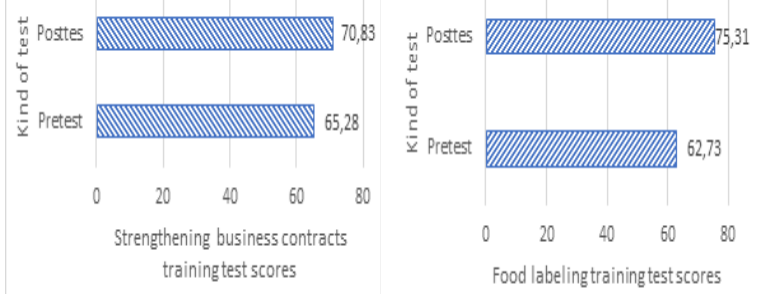

Figure 4. The average value of the pretest and posttest of the trainees

\section{CONCLUSION}

Business contract strengthening training in supporting businesses needs to be known by MSME actors so that they are not deceived and their cooperation with partners can be mutually beneficial. This is expected to develop the business. Food product labeling training is needed to make labels that meet BPOM regulations and attract consumers, so as to improve marketing. All participants participated in the webinar are well, where the average posttest score increased, from 65,28 to 70,83 for business contract training and from 62,73 to 75,31 for food product labeling training.

\section{ACKNOLEDGEMENT}

This community development can be realized in collaboration between the Research and Community Service institute Sahid University and the Head of MSMEs for the Industry, Trade, Cooperatives, Small and Medium Enterprises (Suku Dinas Perindustran, Perdagangan, Koperasi, Usaha Kecil dan Menengah / PPKUKM) Department of South Jakarta Administration.

\section{REFERENCES}

Kitab Undang-Undang Hukum Perdata Buku ke III tentang Perikatan

Undang-Undang No. 8 Tahun 1999 tentang Perlindungan Konsumen

Undang-Undang No. 36 Tahun 2009 tentang Kesehatan, Undang-Undang Nomor 18 tahun 2012 tentang Pangan,

Peraturan Pemerintah No. 69 Tahun1999 tentang Label dan Iklan Pangan,

Permendag No.22/M-DAG/PER/5/2010 tentang Kewajiban Pencantuman Label pada Barang,

Peraturan Menteri Perdagangan RI nomor 73/M-DAG/ PER/9/2015 tentang Kewajiban Pencantuman Label Dalam Bahasa Indonesia Pada Barang.

Perauran badan Pengawas Obat Dan Makanan Nomor 31 tahun 2018 tentang Label Pangan Olahan.

Keputusan Menteri Kesehatan No. 924/Menkes/SK/ VIII/1996 tentang Perubahan Atas Keputusan Menteri Kesehatan RI No, 82/Menkes/SK/I/1996 tentang Pencantuman Tulisan " Halal " pada Label Makanan

Peraturan kepala BPOM nomor 31 tahun 2018 tentang Label Pangan Olahan

Peraturan kepala BPOM nomor 13 tahun 2016 tentang Pengawasan Klaim pada Label dan Iklan Pangan Olahan

Peraturan kepala BPOM no. 23 tahun 2016 tentang pencantuman informasi tanpa BTP pada Label dan Iklan Pangan 
Peraturan kepala BPOM nomor 11 tahun 2019 tentang Bahan Tambahan Pangan

Peraturan kepala BPOM nomor 22 tahun 2019 tentang Informasi Nilai Gizi pada Label Pangan Olahan,
Peraturan kepala BPOM nomor 16 tahun 2020 tentang Pencantuman Informasi Nilai Gizi pada Pangan Olahan yang diproduksi oleh UMK. 